University of Nebraska - Lincoln

DigitalCommons@University of Nebraska - Lincoln

Faculty Publications: Department of

Entomology

Entomology, Department of

2019

Community Composition, Abundance, and Phenology of Stink

Bugs (Hemiptera: Pentatomidae) in Soybean in the North Central

Region of the United States

\author{
Daniela Pezzini \\ University of Minnesota, pezzi004@umn.edu \\ Christina D. DiFonzo \\ Michigan State University, difonzo@msu.edu \\ Deborah L. Finke \\ University of Missouri, finked@missouri.edu \\ Thomas Hunt \\ University of Nebraska-Lincoln, thunt2@unl.edu \\ Janet J. Knodel \\ North Dakota State University, janet.knodel@ndsu.edu
}

See next page for additional authors

Part of the Entomology Commons

Pezzini, Daniela; DiFonzo, Christina D.; Finke, Deborah L.; Hunt, Thomas; Knodel, Janet J.; Krupke, Christian H.; McCornack, Brian P.; Michel, Andrew P.; Philips, Christopher R.; Varenhorst, Adam J.; Wright, Robert J.; and Koch, Robert, "Community Composition, Abundance, and Phenology of Stink Bugs (Hemiptera: Pentatomidae) in Soybean in the North Central Region of the United States" (2019). Faculty Publications: Department of Entomology. 823.

https://digitalcommons.unl.edu/entomologyfacpub/823

This Article is brought to you for free and open access by the Entomology, Department of at DigitalCommons@University of Nebraska - Lincoln. It has been accepted for inclusion in Faculty Publications: Department of Entomology by an authorized administrator of DigitalCommons@University of Nebraska - Lincoln. 


\section{Authors}

Daniela Pezzini, Christina D. DiFonzo, Deborah L. Finke, Thomas Hunt, Janet J. Knodel, Christian H.

Krupke, Brian P. McCornack, Andrew P. Michel, Christopher R. Philips, Adam J. Varenhorst, Robert J.

Wright, and Robert Koch 


\title{
Community Composition, Abundance, and Phenology of Stink Bugs (Hemiptera: Pentatomidae) in Soybean in the North Central Region of the United States
}

\author{
Daniela T. Pezzini, ${ }^{1}$ Christina D. DiFonzo, ${ }^{2}$ \\ Deborah L. Finke, ${ }^{3}$ Thomas E. Hunt, ${ }^{4}$ \\ Janet J. Knodel, ${ }^{5}$ Christian H. Krupke, ${ }^{6}$ \\ Brian McCornack, ${ }^{7}$ Andrew P. Michel, ${ }^{8}$ \\ Christopher R. Philips, ${ }^{1}$ Adam J. Varenhorst, ${ }^{9}$ \\ Robert J. Wright, ${ }^{10}$ and Robert L. Koch ${ }^{1}$
}

1 Department of Entomology, University of Minnesota, 1980 Folwell Avenue, Saint Paul, MN 55108,

2 Department of Entomology, Michigan State University, 243 Natural Science Building, East Leasing, MI 48824-1311,

3 Division of Plant Sciences, University of Missouri-Columbia, Columbia, MO 65211,

4 Department of Entomology, University of Nebraska, Haskell Agricultural Laboratory, 57905866 Road, Concord, NE 68728,

5 Department of Plant Pathology, 210 Walster Hall, North Dakota State University, Fargo, ND 58108-6050,

6 Department of Entomology, Purdue University, 901 West State Street, West Lafayette, IN 47907,

7 Department of Entomology, Kansas State University, 123 W. Waters Hall, 1603 Old Claflin $\mathrm{PI}$, Manhattan, KS 66506,

8 Department of Entomology, Ohio Agricultural Research and Development Center, The Ohio State University, 210 Thorne, 1680 Madison Avenue, Wooster, OH 4469,

9 Department of Agronomy, Horticulture and Plant Science, South Dakota State University, SAG 220, Brookings, SD 57007,

10 Department of Entomology, University of Nebraska-Lincoln, 213 Entomology Hall, Lincoln, NE 68583-0816

Corresponding author — R.L. Koch, email koch0125@umn.edu

Published in Journal of Economic Entomology, 112:4 (2019), pp 1722-1731.

doi: 10.1093/jee/toz099

Copyright $($ by the Authors. Published by Oxford University Press on behalf of

Entomological Society of America. Used by permission.

Submitted 3 December 2018; accepted 27 March 2019 


\begin{abstract}
Stink bugs (Hemiptera: Pentatomidae) are an increasing threat to soybean (Fabales: Fabaceae) production in the North Central Region of the United States, which accounts for $80 \%$ of the country's total soybean production. Characterization of the stink bug community is essential for development of management programs for these pests. However, the composition of the stink bug community in the region is not well defined. This study aimed to address this gap with a 2-yr, 9-state survey. Specifically, we characterized the relative abundance, richness, and diversity of taxa in this community, and assessed phenological differences in abundance of herbivorous and predatory stink bugs. Overall, the stink bug community was dominated by Euschistus spp. (Hemiptera: Pentatomidae) and Chinavia hilaris (Say) (Hemiptera: Pentatomidae). Euschistus variolarius (Palisot de Beauvois) (Hemiptera: Pentatomidae), C. hilaris and Halyomorpha halys (Stål) (Hemiptera: Pentatomidae) were more abundant in the northwestern, southeastern and eastern parts, respectively, of the North Central Region of the United States. Economically significant infestations of herbivorous species occurred in fields in southern parts of the region. Species richness differed across states, while diversity was the same across the region. Herbivorous and predatory species were more abundant during later soybean growth stages. Our results represent the first regional characterization of the stink bug community in soybean fields and will be fundamental for the development of state- and region-specific management programs for these pests in the North Central Region of the United States.
\end{abstract}

Keywords: Euschistus variolarius, Chinavia hilaris, Halyomorpha halys, species composition, relative abundance

Soybean, Glycine max (L.) Merr. (Fabales: Fabaceae), is the most valuable bean in the world due to its high nutritional value (Wilcox 2004). The United States is the largest global soybean producer, and the North Central Region of the United States is responsible for $80 \%$ of the country's total soybean production (NASS 2018). Stink bugs (Hemiptera: Pentatomidae) are among the most important insect pests of this crop, because they feed primarily on pods, causing irreversible direct damage to developing seeds (McPherson and McPherson 2000). Although historically insignificant as pests in the North Central Region of the United States, stink bugs pose an emerging threat to soybean production, because of the introduction and spread of invasive species and the reported increase in abundance of native species.

In the North Central Region of the United States, at least 67 stink bug species are found, 23 of which are reported in soybean (Packauskas 2012; Sites et al. 2012; Swanson 2012; Koch et al. 2014, 2017). Economically important herbivorous stink bugs belong to the subfamily Pentatominae and are well-recognized as pests of many crops 
(McPherson and McPherson 2000). The family Pentatomidae also includes beneficial (i.e., predatory) species in the subfamily Asopinae. This subfamily includes well-known predators of insect pests of economic importance (De Clercq 2000, McPherson and McPherson 2000). The spined soldier bug, Podisus maculiventris (Say) (Hemiptera: Pentatomidae), is the most common predatory species in the United States (McPherson 1982, De Clercq 2000).

Invasive stink bugs are particularly important to soybean because of their polyphagy and ability to adapt to new environments (Panizzi 2015, McPherson 2018). The brown marmorated stink bug, Halyomorpha halys (Stål) (Hemiptera: Pentatomidae), was first detected in Pennsylvania in 1996 (Hoebeke and Carter 2003). Since its introduction, $H$. halys spread to 44 U.S. states, including 11 of 12 states in the North Central Region of the United States (Northeastern IPM Center 2018). In the Mid-Atlantic Region, $H$. halys is well established, and growers report up to $50 \%$ yield reduction in soybean due to this pest (Leskey et al. 2012). In addition, the red-banded stink bug, Piezodorus guildinii (Westwood) (Hemiptera: Pentatomidae), an important pest of soybean in the South America, has been detected in Missouri (Tindall and Fothergill 2011) and in many Southeastern U.S. states (Panizzi and Slansky 1985, McPherson et al. 1993, Smith et al. 2009). Particularly, it became the most abundant stink bug species in soybean in Louisiana (Temple et al. 2013) and Texas (Vyavhare et al. 2014). The economic importance of $P$. guildinii is further related to the greater damage it causes to soybean seeds when it is compared to other native species in the South America (Corrêa-Ferreira and Azevedo 2002, Depieri and Panizzi 2011). Moreover, the painted bug, Bagrada hilaris (Burmeister) (Hemiptera: Pentatomidae), originally from India and first reported in the United States in California in 2008, was recently detected in Minnesota (Koch et al. 2018). This species has reached economic importance in California and Arizona cruciferous crops (Palumbo and Natwick 2010) and, although it feeds preferentially on plants of the family Brassicaceae, it may also feed on soybean (Reed et al. 2013).

In addition to the threat posed by new invasive stink bug species, the abundance of native species such as the green stink bug, Chinavia hilaris (Say) (Hemiptera: Pentatomidae), brown stink bug, Euschistus servus (Say) (Hemiptera: Pentatomidae), one-spotted stink bug, $E$. variolarius (Palisot de Beauvois) (Hemiptera: Pentatomidae), and redshouldered stink bug, Thyanta custator accerra McAtee (Hemiptera: 
Pentatomidae), also is increasing in soybean in the North Central Region of the United States (Hunt et al. 2011, 2014; Michel et al. 2015, Koch et al. 2017). The factors contributing to increased abundance of native species are unknown, but may be related to increasing temperatures or greater use of reduced-tillage cultivation systems (Panizzi 2015, McPherson 2018). Because of their historical insignificance as pests of soybean in much of the region, little is known about the stink bug community in this key production region. Therefore, assessment of community composition of stink bugs in the North Central Region of the United States is needed.

The objective of this study was to characterize the community composition and phenological dynamics of stink bugs in soybean in the North Central Region of the United States. This work directly relates to the development of stink bug management recommendations because host range (McPherson and McPherson 2000, Panizzi et al. 2000, Koch et al. 2017), damage-potential (Sosa-Gómez and Moscardi 1995, Depieri and Panizzi 2011, Corrêa-Ferreira and Azevedo 2002) and insecticide susceptibility (Willrich et al. 2003, Snodgrass et al. 2005, Kamminga et al. 2009, Hopkins et al. 2010) vary among species. Furthermore, data on stink bug community composition in soybean provide a baseline to document shifts resulting from invasive species and changes in production practices and climate.

\section{Materials and Methods}

\section{Study Sites and Data Collection}

Stink bugs were sampled following a standardized protocol in soybean fields distributed across nine states in the North Central Region of the United States during 2016 and 2017 (Fig. 1). In 2016, data were from study sites in Indiana, Kansas, Minnesota, Missouri, Nebraska, North Dakota, and South Dakota. In 2017, data were from study sites in Indiana, Michigan, Minnesota, Missouri, Nebraska, North Dakota, Ohio and South Dakota (Fig. 1). A total of 50 and 51 soybean fields were sampled in 2016 and 2017, respectively, with field sizes ranging from 0.5 to 120 ha (mean \pm SEM: $17.9 \pm 2.1$ ha). In each state, fields were grouped at one to four sites, with sites separated by 13 to $368 \mathrm{~km}$. Fields were on university research stations or cooperating farms, with 


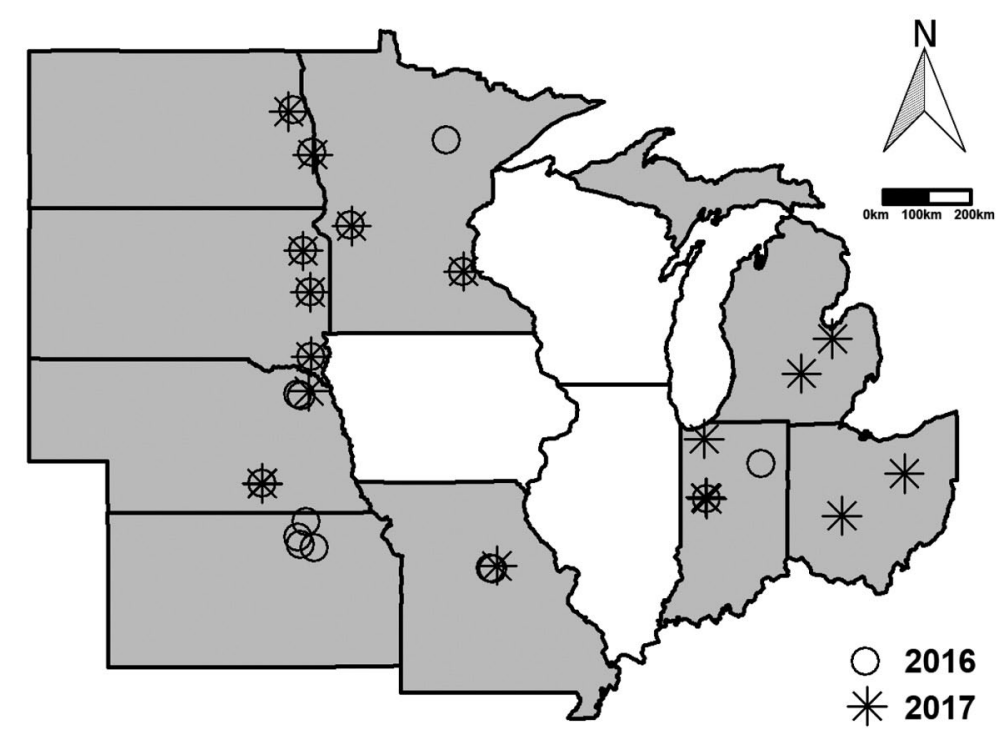

Fig. 1. Locations where soybean fields were sampled for stink bugs in the North Central Region of the United States in 2016 and 2017. In each year, one to four soybean fields were sampled per location.

soybean row spacing of $76.2 \mathrm{~cm}$. Soybean varieties, planting dates and management practices were representative of the respective states.

Stink bugs were sampled with sweep nets (net diameter $=39 \mathrm{~cm}$ ) between the R1 (i.e., 'beginning bloom') and R8 (i.e., 'full maturity') soybean growth stages (Fehr and Caviness 1977). Fields were sampled for a minimum of four sample dates over the growing season to capture phenological dynamics of the fauna. Generally, 12 sample units were collected from fields on each sample date; however, additional sample units were occasionally taken at some locations. A sample unit consisted of a set of 25 sweeps. Once a sample unit was collected, contents of the net were transferred to a labeled $20.3 \times 25.4-\mathrm{cm}$ zippered plastic bag, which was placed in a cooler and transported to the laboratory. The season-long number of sample units (i.e., sets of 25 sweeps) collected per field ranged from 96 to 120 in Indiana, 6072 in Kansas, 48-84 in Michigan, 72-236 in Minnesota, 60-72 in Missouri, 48-96 in Nebraska, 60-72 in North Dakota, 60-96 in South Dakota, and 48-60 in Ohio. Rough sorting of the samples to remove plant material and nontarget insects was performed in laboratories in each state. Samples with stink bugs were kept in the freezer and were sent to the University of Minnesota where nymphs were identified to genus or species and adults were identified to species or subspecies. 
Identifications were based on DeCoursey and Esselbaugh (1962) and Evans (1985) for nymphs and McPherson and McPherson (2000), Rider (2012), and Paiero et al. (2013) for adults. Nymphs of Euschistus were identified to genus, because the species of this genus are difficult to distinguish in this life stage. Voucher specimens of each species were placed in the University of Minnesota Insect Collection in St. Paul, Minnesota.

\section{Data Analyses}

For all analyses, species or subspecies of adults and genera of nymphs that accounted for less than $0.5 \%$ of the total number of individuals for the respective life stage were removed from analyses (Tables 1 and 2). This approach was taken because rare species were deemed as less relevant as pests or natural enemies (e.g., Kleijn et al. 2015, Winfree et al. 2015).

\section{Relative Abundance}

We examined differences in relative abundances of species to compare the stink bug community and determine the most abundant species in soybean fields in the North Central Region of the U.S. Analyses of relative abundance were performed separately for nymphs and adults by state with $\mathrm{R}$ version 3.4.4 (R Core Team 2018). Friedman's nonparametric test (package, code: rcompanion, friedman.test; Mangiafico 2018) was used to compare the relative abundance of the predominant taxa of stink bug adults and nymphs for each state and post hoc multiple comparison was performed (rcompanion, pairwisesignTest; Mangiafico 2018). Friedman's test was used to take account of the lack of independence among taxa in data presented as relative abundance (i.e., \% that each taxon represented of total).

\section{Species Richness and Diversity}

Species richness (i.e., number of species) and diversity of the stink bug community was estimated for each field over the season. For these analyses, subspecies were combined within species because of similar biology (McPherson 1982) and to avoid overestimation of species richness and diversity when subspecies of the same species were detected in the same field. For assessment of richness, the presence 
or absence of adults of each species (i.e., 9 total) was determined for each sample unit (i.e., sets of 25 sweeps). A nonparametric method, Chao2, was used for estimation of species richness for each field (Chao 1987, Colwell and Coddington 1994). Chao2 estimates species richness for sample-based incidence (presence/absence) data based on occurrence of 'singletons' (i.e., species that occur in only one sample unit across the season) and 'doubletons' (i.e., species that occur in two sample units across the season) (Colwell and Coddington 1994). Chao2 is a robust species richness estimator that has been used in other systems (Colwell and Coddington 1994, Barcellos et al. 2008, Baz et al. 2014, Mokam et al. 2014, Acosta et al. 2017). It was chosen as the richness estimator in this study to account for the uneven number of sample units taken over the season from different fields.

To assess diversity, the number of adults of each species was summed within sample units. Species diversity was estimated by the Simpson inverse diversity index using Estimate S (version 9) (Colwell et al. 2012). This is a robust index that accounts for both number of species and abundance of each species, applying more weight to the most abundant species (Simpson 1949). Because the total sampling effort was not the same for each field, rarefaction curves, resampled 100 times, were created using EstimateS (Colwell et al. 2012). Then, calculation of Simpson's index at 48 sample units (i.e., the lowest total number of sample units collected from a field) was used to standardize sampling effort for different fields. The software could not compute richness and diversity estimates for fields where the most abundant species had fewer than two individuals; only one such field was removed from analysis.

Generalized linear mixed models (GLMM) were used to test the effect of year (i.e., 2 yr) and state (i.e., 9 states) on stink bug species richness (Chao2) or diversity (Simpson's index), with site as a random effect (Ime4, Imer; Bates et al. 2015). Analyses were performed with $R$ version 3.4.4 (R Core Team 2018) and assumptions were checked by inspection of the residual plots. Tukey-Kramer-adjusted pairwise comparisons of least square means were used to determine significant differences $(\alpha=0.05)$ among treatments for analyses of stink bug species richness (Chao2) and diversity (Simpson's index) (multcomp, glht; Hothorn et al. 2008). 
Phenology and Maximum Abundance

The phenology of stink bugs in soybean was assessed to determine which soybean growth stages were more likely to have economic infestation of herbivorous species and higher numbers of predatory species. Stink bug phenology in soybean was summarized by averaging the mean densities of the nymph and adult life stages of herbivorous or predatory stink bugs by soybean growth stage across fields and years.

Maximum mean abundance of herbivorous and predatory stink bugs was calculated as the peak mean density (i.e., stink bugs/ 25 sweeps) for each field across the season. GLMMs were used to test the effect of year (i.e., $2 \mathrm{yr}$ ) and state (i.e., 9 states) on maximum mean abundance $(\log x+1)$ of herbivorous or predatory stink bugs, with site as a random effect. Analyses were performed with $\mathrm{R}$ version 3.4.4 ( $R$ Core Team 2018) and assumptions were checked by inspection of the residual plots. Tukey-Kramer-adjusted pairwise comparisons of least square means were used to determine significant differences ( $\alpha$ $=0.05$ ) among treatments for herbivorous and predatory stink bug mean maximum abundance (multcomp, glht; Hothorn et al. 2008).

\section{Results}

Analyses were performed on a total of 704 samples (i.e., 9,457 sample units of 25 sweeps) collected from 101 soybean fields across 9 states and 2 yr. From these samples, a total of 5,794 stink bug specimens were collected, of which 1,968 were adults and 3,826 were nymphs (Tables 1 and 2).

\section{Relative Abundance}

Across years and states, a total of 19 species and subspecies of adults (i.e., 17 herbivores and two predators) (Table 1) and seven genera of nymphs (i.e., six herbivores and one predator) were collected (Table 2). Euschistus variolarius was the most abundant adult, followed by C. hilaris, Euschistus servus (i.e., E. s. servus, E. s. euschistoides and E. s. hybrid), P. maculiventris, E. tristigmus (i.e., E. t. tristigmus and E. t. luridus), T. c. accerra and $H$. halys (Table 1 ). A similar pattern was observed for nymphs, where Euschistus spp. were the most abundant, followed by 
Table 1. Relative abundance of taxa of stink bug adults collected in soybean across nine states in 2016 and 2017 in the North Central Region of the United States

\begin{tabular}{|c|c|c|c|c|}
\hline \multirow[b]{2}{*}{ Species } & \multicolumn{3}{|c|}{ Total number of individuals } & \multirow{2}{*}{$\begin{array}{l}\text { (\%) Rel. } \\
\text { abundance }\end{array}$} \\
\hline & 2016 & 2017 & Total & \\
\hline \multicolumn{5}{|l|}{ Subfamily: Pentatominae } \\
\hline Banasa dimidiata & 0 & 1 & 1 & 0.05 \\
\hline Chinavia hilaris & 493 & 190 & 683 & 34.71 \\
\hline Coenus delius & 2 & 0 & 2 & 0.10 \\
\hline Cosmopepla lintneriana & 6 & 2 & 8 & 0.41 \\
\hline Euschistus servus servus & 26 & 28 & 54 & 2.74 \\
\hline Euschistus servus euschistoides & 24 & 14 & 38 & 1.93 \\
\hline Euschistus servus hybrid & 25 & 8 & 33 & 1.68 \\
\hline Euschistus tristigmus luridus & 22 & 14 & 36 & 1.83 \\
\hline Euschistus tristigmus tristigmus & 13 & 12 & 25 & 1.27 \\
\hline Euschistus variolarius & 450 & 421 & 871 & 44.26 \\
\hline Halyomorpha halys & 3 & 28 & 31 & 1.58 \\
\hline Holcostethus limbolarius & 2 & 1 & 3 & 0.15 \\
\hline Mormidea lugens & 1 & 0 & 1 & 0.05 \\
\hline Oebalus pugnax & 8 & 0 & 8 & 0.41 \\
\hline Thyanta calceata & 3 & 3 & 6 & 0.30 \\
\hline Thyanta custator accerra & 55 & 4 & 59 & 3.00 \\
\hline Trichopepla semivittata & 1 & 0 & 1 & 0.05 \\
\hline \multicolumn{5}{|l|}{ Subfamily: Asopinae } \\
\hline Apoecilus cynicus & 1 & 1 & 2 & 0.10 \\
\hline Podisus maculiventris & 69 & 37 & 106 & 5.39 \\
\hline
\end{tabular}

Table 2. Relative abundance of taxa of stink bug nymphs collected in soybean across nine states in 2016 and 2017 in the North Central Region of the United States

\begin{tabular}{lrrrr} 
& \multicolumn{5}{c}{ Total number of individuals } & $\begin{array}{r}\text { (\%) Rel. } \\
\text { Species }\end{array}$ \\
\cline { 5 - 5 } & 2016 & 2017 & \multicolumn{1}{c}{ Total } & abundance \\
\hline Subfamily: Pentatominae & & & & \\
$\quad$ Chinavia hilaris & 925 & 278 & 1,203 & 31.44 \\
$\quad$ Chlorochroa spp. & 0 & 1 & 1 & 0.03 \\
Euschistus spp. & 1,551 & 906 & 2,457 & 64.22 \\
Halyomorpha halys & 44 & 42 & 86 & 2.25 \\
$\quad$ Oebalus pugnax & 1 & 1 & 2 & 0.05 \\
$\quad$ Thyanta spp. & 11 & 8 & 19 & 0.50 \\
Subfamily: Asopinae & & & & \\
$\quad$ Podisus spp. & 40 & 18 & 58 & 1.52 \\
\hline
\end{tabular}


C. hilaris, H. halys, Podisus spp. and Thyanta spp. (Table 2). Combining nymphs and adults, 10 stink bug taxa accounted for $99.4 \%$ of individuals in soybean fields (Tables 1 and 2). Ten additional taxa accounted for less than $0.6 \%$ of the total number of stink bugs collected in this study (Tables 1 and 2).

Relative abundance of species and subspecies of stink bug adults (after exclusion of rare species) differed significantly within each state (Friedman test results: Indiana $\left[\chi^{2}=83.2, \mathrm{df}=9, P<0.001\right]$, Kansas $\left[\chi^{2}=35.3, \mathrm{df}=9, P<0.001\right]$, Michigan $\left[\chi^{2}=51.7, \mathrm{df}=9, P<0.001\right]$, Minnesota $\left[\chi^{2}=98.2, \mathrm{df}=9, P<0.001\right]$, Missouri $\left[\chi^{2}=65.0, \mathrm{df}=9\right.$, $P<0.001]$, Nebraska [ $\left.\chi^{2}=96.1, \mathrm{df}=9, P<0.001\right]$, North Dakota [ $\chi^{2}=70.9$, $\mathrm{df}=9, P<0.001]$, Ohio $\left[X^{2}=41.5, \mathrm{df}=9, P<0.001\right]$, South Dakota $\left[X^{2}=42.6, d f=9, P<0.001\right]$; Fig. 2). For adults, E. variolarius was generally more abundant in states in the northwestern part of the region (including Kansas, Michigan, Minnesota, Nebraska, North Dakota and South Dakota) and C. hilaris was generally more abundant in states in the southeastern part of the region (including Indiana, Missouri and Ohio; Fig. 2). Similarly, the relative abundance of genera of nymphs differed significantly within each state (Friedman test results: Indiana $\left[X^{2}=50.4, \mathrm{df}=4, P<0.001\right]$, Kansas $\left[X^{2}=16.1\right.$, $\left.\mathrm{df}=4, P=0.002\right]$, Michigan $\left[X^{2}=25.1, \mathrm{df}=4, P<0.001\right]$, Minnesota $\left[X^{2}=49.6, \mathrm{df}=4\right.$, $P<0.001]$, Missouri $\left[\chi^{2}=45.4, \mathrm{df}=4, P<0.001\right]$, Nebraska $\left[\chi^{2}=43.6\right.$, $\mathrm{df}=4, P<0.001]$, North Dakota $\left[\chi^{2}=40.9, \mathrm{df}=4, P<0.001\right]$, Ohio $\left[\mathrm{X}^{2}=22.6, \mathrm{df}=4, P<0.001\right]$, South Dakota $\left[\mathrm{X}^{2}=16, \mathrm{df}=4, P=0.003\right]$;

Fig. 3). For nymphs, Euschistus spp. were generally more abundant in states in the northwestern part of the region (including Kansas, Michigan, Minnesota, Nebraska, North Dakota, and South Dakota) and C. hilaris was generally more abundant in states in the southeastern part of the region (including Indiana, Missouri and Ohio) (Fig. 3). Halyomorpha halys adults and nymphs were most abundant in states in the eastern part of the region (including Indiana and Michigan), and were rare or not detected in the remaining states (Figs. 2 and 3). The other invasive stink bugs, P. guildinii and B. hilaris were not detected in this study.

\section{Species Richness and Diversity}

Chao2 richness indices differed significantly across states $\left(\chi^{2}=24.327\right.$, $\mathrm{df}=8, P<0.01)$, but not between years $\left(\chi^{2}=0.040, \mathrm{df}=1, P=0.841\right)$ 

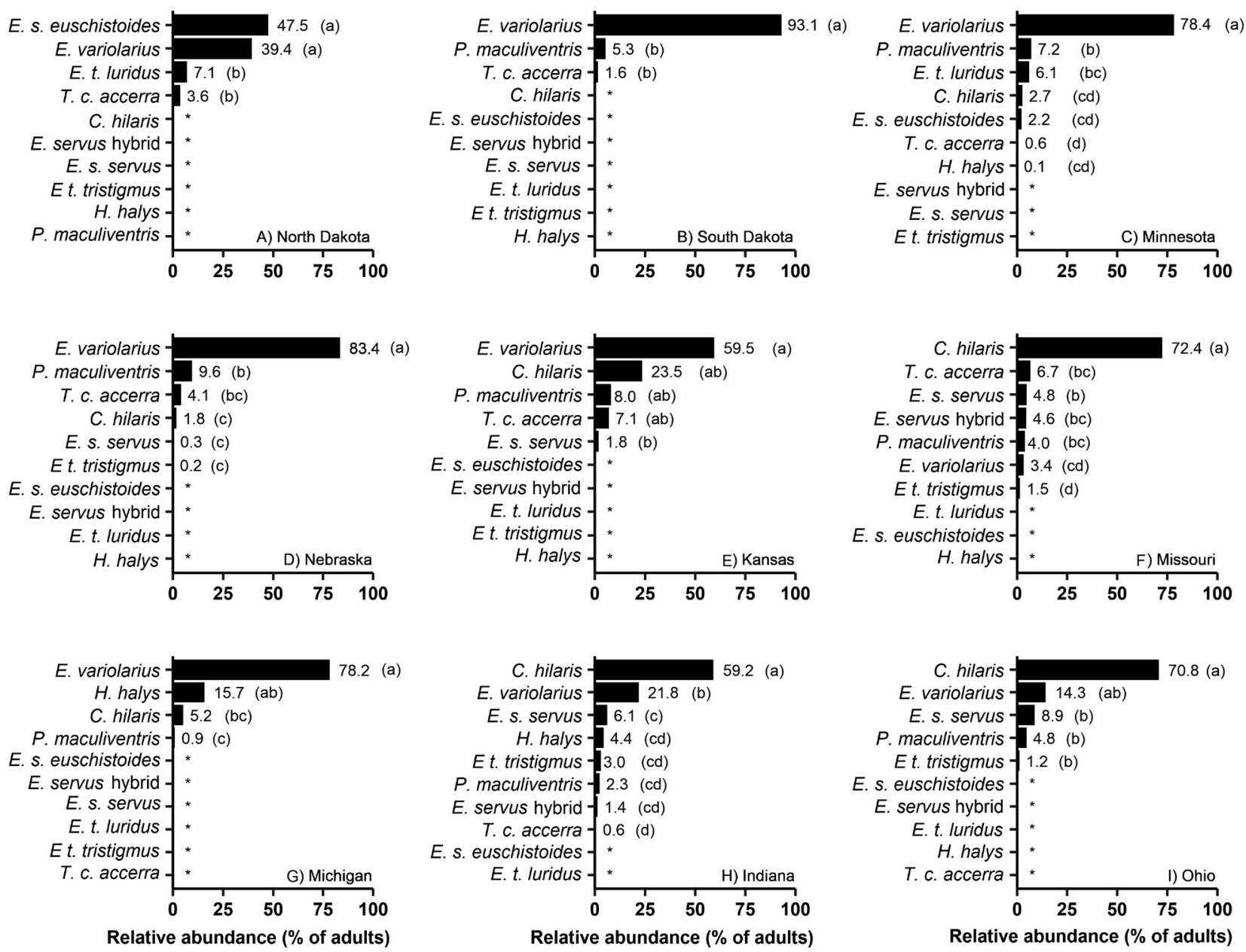

Fig. 2. Relative abundance (\%) of species of stink bug adults collected in soybean across nine states in 2016 and 2017 in the North Central Region of the United States. Numbers after bars indicate mean values. Means followed by the same letter are not significantly different at $\alpha=0.05$ using Friedman test and post hoc multiple comparisons. Asterisks $(*)$ indicate that the species or subspecies was not detected in the state. All species listed here are herbivores, except for $P$. maculiventris, which is predatory.

(Fig. 4). Across years, Missouri had the highest index for species richness (4.5 \pm 0.4$)$ (Fig. 4). Indiana (4.0 \pm 0.3 ) had the second highest index for species richness, but it did not differ from those of Minnesota (3.2 \pm 0.3 ) or Missouri (Fig. 4). To compare species diversity across states, sample-based rarefaction curves were created for each field and data were standardized by interpolating to a sample effort of 48 sample units. Simpson's diversity indices did not differ significantly across states $\left(\chi^{2}=8.783, \mathrm{df}=8, P=0.360\right)$ or years $\left(\chi^{2}=0.054\right.$, df $=1$, $P=0.814)$. 

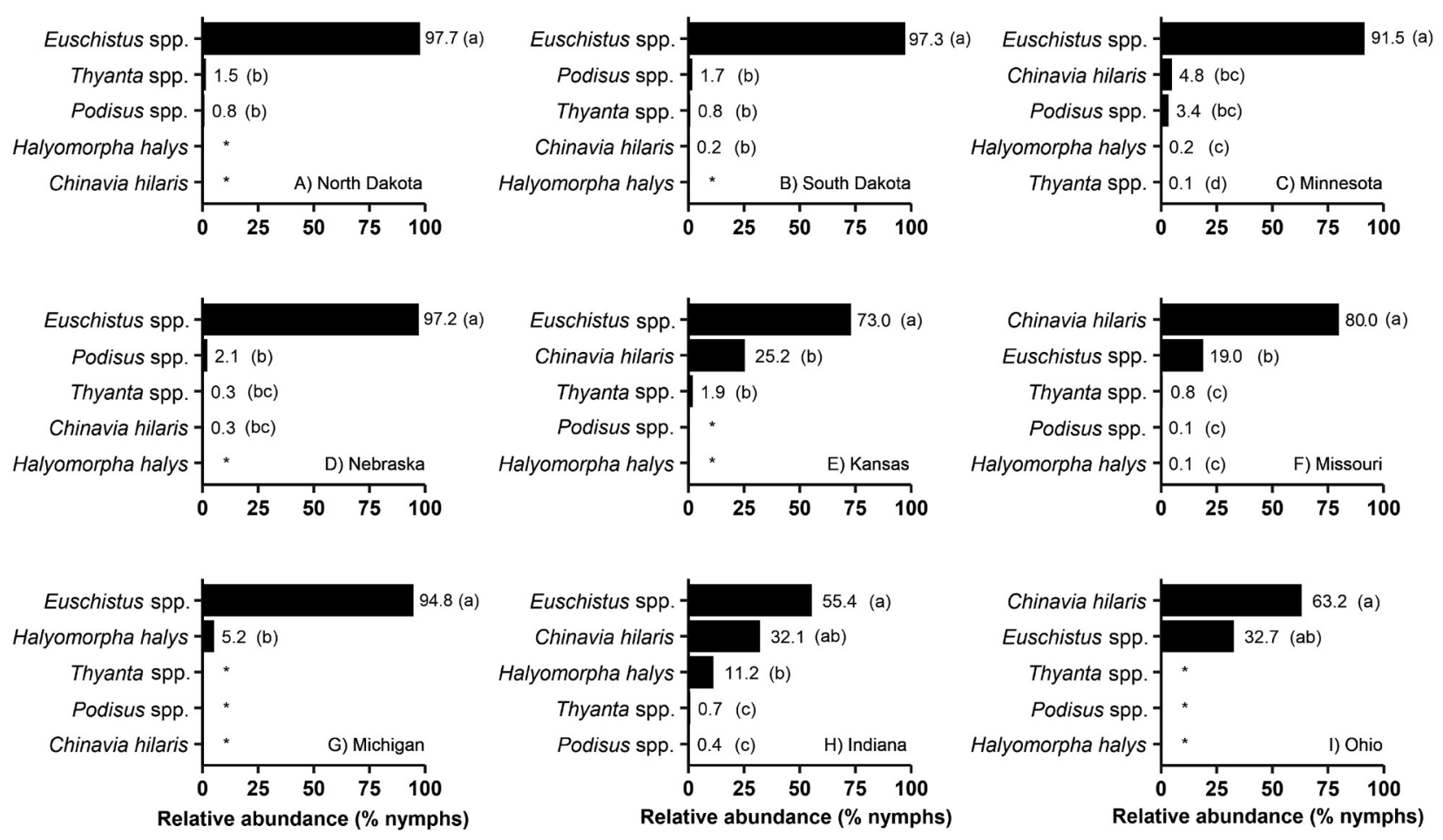

Fig. 3. Relative abundance (\%) of genera of stink bug nymphs collected in soybean across 9 states in 2016 and 2017 in the North Central Region of the United States. Numbers after bars are mean values. Means followed by the same letter are not significantly different at $\alpha=0.05$ using Friedman test and post hoc multiple comparisons. Asterisks $\left(^{*}\right)$ indicate that the stink bug genus was not detected in the state. All genera listed here are herbivores, except for Podisus spp., which is predatory.

\section{Phenology and Maximum Abundance}

Across years and locations, mean density (i.e., stink bugs/ 25 sweeps) of herbivorous adult stink bugs peaked first in 'full bloom' (R2) and again in the 'full seed' (R6) soybean growth stages (Fig. 5A). Mean density of herbivorous nymphs and total herbivorous stink bugs (i.e., nymphs and adults) peaked in the 'beginning maturity' (R7) soybean growth stage (Fig. 5A). For predatory stink bugs, mean density of adults peaked in the 'full pod set' (R4) soybean growth stage (Fig. 5B). Mean density of predatory nymphs and total predatory stink bugs (i.e., nymphs and adults) peaked in the 'beginning maturity' (R7) soybean growth stage (Fig. 5B). 


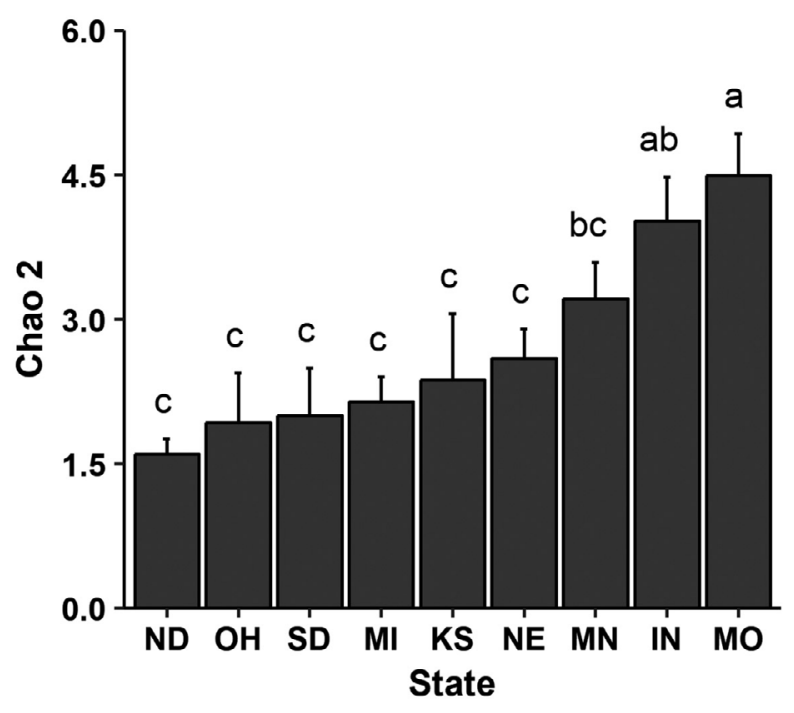

Fig. 4. Mean ( \pm SEM) Chao2 species richness for soybean stink bug communities sampled in 2016 and 2017 across fields for 9 states in the North Central Region of the United States (IN = Indiana, KS = Kansas, $\mathrm{MI}=$ Michigan, $\mathrm{MN}=$ Minnesota, $\mathrm{MO}$ $=$ Missouri, NE = Nebraska, ND = North Dakota, $\mathrm{OH}=$ Ohio, SD = South Dakota). Means with same letters are not significantly different at $\alpha=0.05$ using TukeyKramer-adjusted pairwise comparisons of least square means.
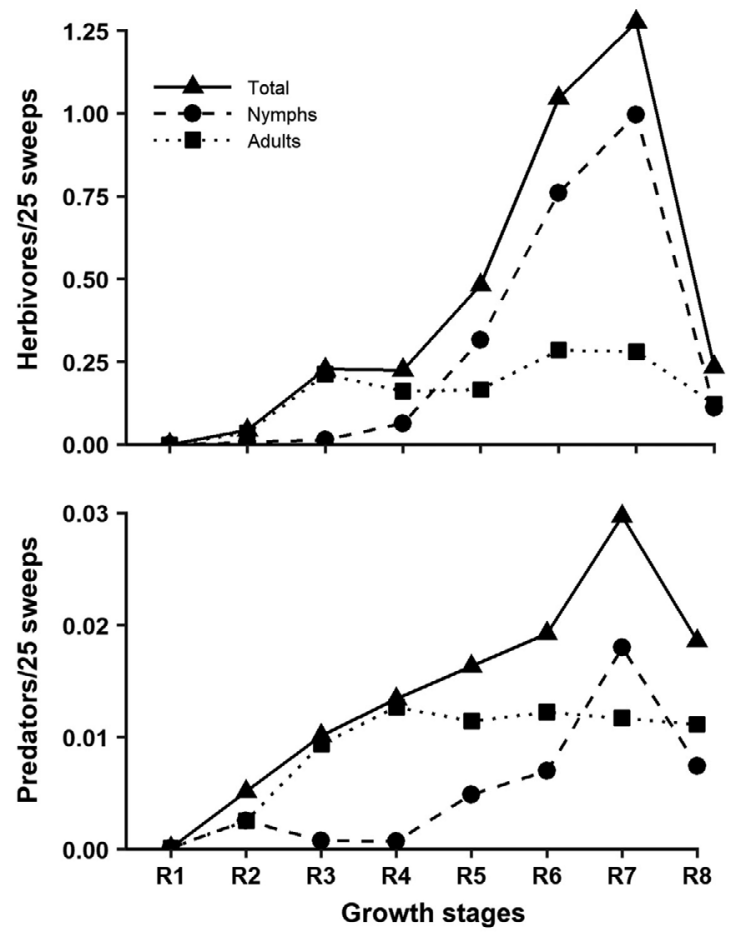

Fig. 5. Mean abundance of herbivorous (A) and predatory (B) stink bugs from beginning bloom (R1) through full maturity (R8) soybean growth stages across years and fields in the North Central Region of the United States. 
Across states, herbivorous stink bug maximum mean density per field ranged from 0 to 15.2 stink bugs/ 25 sweeps in 2016, and from 0 to 4.1 stink bugs/ 25 sweeps in 2017. For herbivores, there was a significant difference in stink bug maximum mean density across states and it was higher in 2016 than in 2017 (i.e., significant interaction) $\left(X^{2}=29.974, d f=5, P<0.001\right)$ (Fig. 6A and B). Except for Ohio and Kansas, higher herbivorous maximum mean density occurred
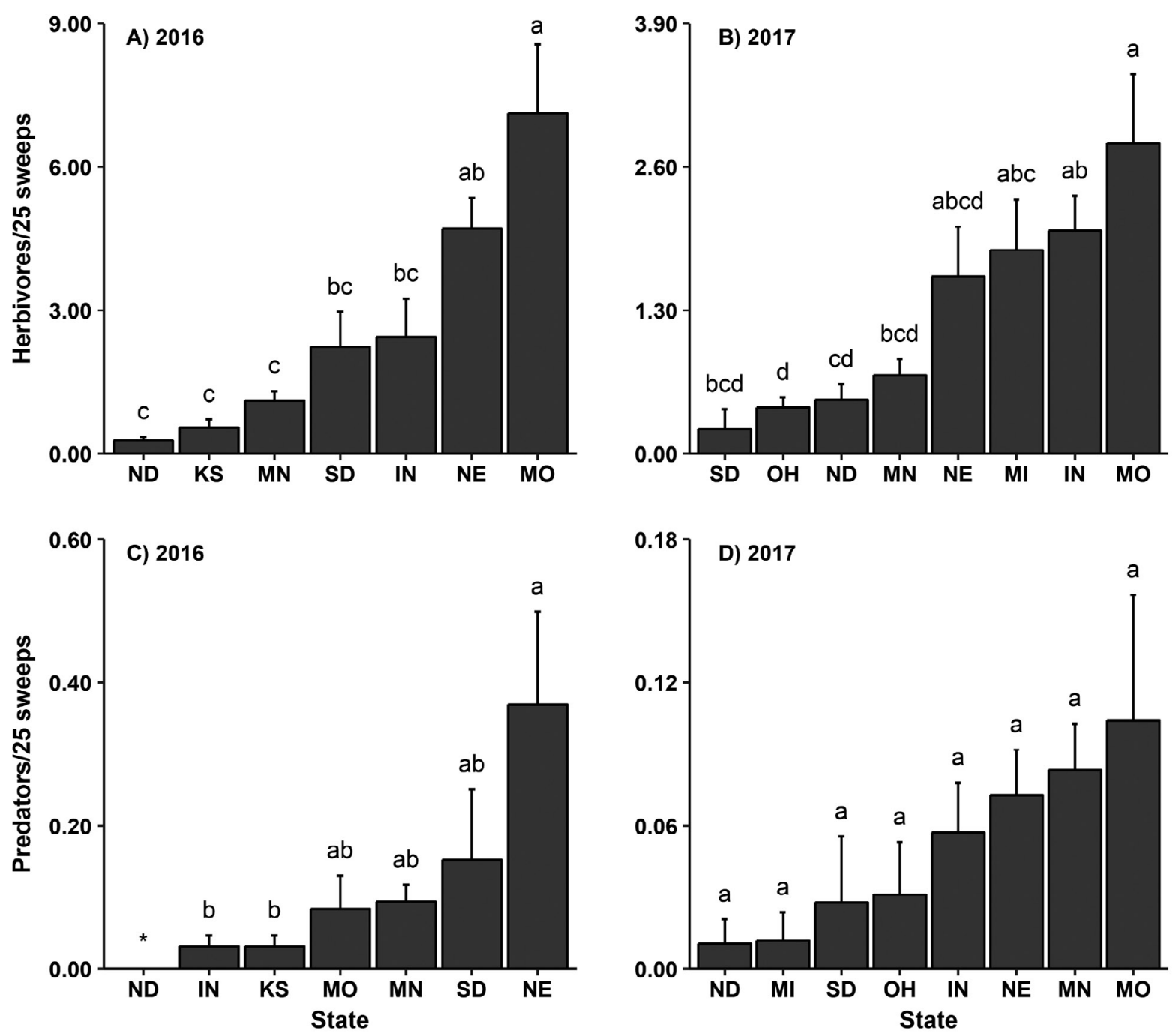

Fig. 6. Mean $( \pm$ SEM) maximum abundance of herbivorous $(\mathbf{A}, \mathbf{B})$ and predatory $(\mathbf{C}$, D) stink bugs in soybean fields for states in the North Central Region of the United States (IN = Indiana, $\mathrm{KS}=$ Kansas, $\mathrm{MI}=$ Michigan, $\mathrm{MN}=$ Minnesota, $\mathrm{MO}=$ Missouri, NE = Nebraska, ND = North Dakota, $\mathrm{OH}=$ Ohio, SD = South Dakota) in 2016 (A, C) and 2017 (B, D). Means with same letters are not significantly different at $\alpha$ $=0.05$ using Tukey-Kramer-adjusted pairwise comparisons of least square means. Asterisks ( $\left.{ }^{*}\right)$ indicate zero. 
in southern states. In both years, the highest herbivorous maximum mean abundance was observed in Missouri (2016: $7.0 \pm 1.4$ bugs/25 sweeps; 2017: $2.8 \pm 0.6$ ). Stink bug maximum density in Missouri did not differ from Nebraska in both years (2016: $4.7 \pm 0.6 ; 2017: 1.6 \pm 0.4$ ) or from Indiana (2.0 \pm 0.3 ) and Michigan (1.8 \pm 0.4) in 2017 .

For predatory stink bugs, maximum mean density ranged from 0.0 to 0.83 stink bugs/ 25 sweeps in 2016, and from 0.0 to 0.2 stink bugs/ 25 sweeps in 2017. Maximum mean density was significantly different across states $\left(X^{2}=18.484, \mathrm{df}=8, P=0.02\right)$ and significantly higher in 2016 than in 2017 ( $\chi^{2}=5.677$, df $=1, P=0.02$ ) (Fig. 6C and D). In 2016, Nebraska $(0.21 \pm 0.07)$ had the highest maximum mean density of stink bugs, followed by South Dakota (0.12 \pm 0.07$)$, Minnesota (0.07 \pm 0.01$)$, and Missouri (0.09 \pm 0.12$)$. In 2017, Missouri had the highest maximum mean abundance of predatory stink bugs numerically, but not statistically.

\section{Discussion}

Stink bugs are an emerging threat to soybean in the North Central Region of the United States (Hunt et al. 2011, 2014; Michel et al. 2015; Koch et al. 2017). However, because of their history as minor pests of soybean in much of the region, there is a lack of region-specific knowledge about this pest complex. Here, we present the first regional characterization of the stink bug community in soybean fields across this key soybean producing region.

A total of 20 stink bug species and subspecies (nymphs and adults combined) were collected across the states and years sampled (Tables 1 and 2). All of these taxa were previously reported to occur in the region (McPherson 1982; Packauskas 2012; Rider 2012; Sites et al. 2012; Swanson 2012; Koch et al. 2014, 2017). Among these species, the herbivores E. variolarius, E. tristigmus, E. servus, C. hilaris, $H$. halys, T. c. accerra and the predator P. maculiventris accounted for over $98 \%$ of the stink bug community. Similar results were observed in previous studies in Minnesota soybean (Koch and Pahs 2014, Koch and Rich 2015). Management recommendations for stink bugs in soybean in the North Central Region of the United States should consider differences in biology and pest potential among these species (McPherson and McPherson 2000, Koch et al. 2017). In particular, 
susceptibility to pesticides was reported to vary between the native species E. servus and C. hilaris (Willrich et al. 2003, Snodgrass et al. 2005, Kamminga et al. 2009), while damage caused to soybean was similar among $C$. hilaris, E. servus, and E. tristigmus (McPherson et al. 1979, Jones and Sullivan 1982, McPherson and McPherson 2000). However, these studies did not include E. variolarius, the most abundant species in our study. Future studies should compare the susceptibility to pesticides and damage potential to soybean of E. variolarius compared to other species.

Several species (i.e., Apoecilus cynicus (Say) (Hemiptera: Pentatomidae), Banasa dimidiata (Say) (Hemiptera: Pentatomidae), Chlorochroa spp. (Hemiptera: Pentatomidae), Coenus delius (Say) (Hemiptera: Pentatomidae), Cosmopepla lintneriana (Kirkaldy) (Hemiptera: Pentatomidae), Holcostethus limbolarius (Stål) (Hemiptera: Pentatomidae), Mormidea lugens (Fabricius) (Hemiptera: Pentatomidae), Oebalus pugnax (Fabricius) (Hemiptera: Pentatomidae), T. calceata (Say) (Hemiptera: Pentatomidae), and Trichopepla semivittata (Say) (Hemiptera: Pentatomidae)) were detected infrequently in this study. Their low abundance in soybean fields may be due to a preference for other hosts (i.e., grasses, small grains, wild hosts, ornamental plants and small fruits). It is likely that their presence in soybean was incidental, as reported by others in the region (McPherson and McPherson 2000, Koch and Pahs 2014, Koch et al. 2017, Pezzini et al. 2018).

The composition of the stink bug community in soybean in the North Central Region of the United States differed from that reported in other regions. In the Mid-Atlantic Region, $H$. halys was reported as the most abundant stink bug species in soybean in 2009 (Nielsen and Hamilton 2009). In the southern United States, the stink bug community is comprised mostly of Nezara viridula (Linnaeus) (Hemiptera: Pentatomidae), C. hilaris, and E. servus (McPherson et al. 1993, Smith et al. 2009). More recently, the invasive $P$. guildinii became the most abundant species in Louisiana and Texas soybean (Temple et al. 2013, Vyavhare et al. 2014).

Across years, our results demonstrated that stink bug species richness (i.e., Chao2) differed across states, while diversity (i.e., Simpson's index) was the same across the region. The lack of differences in diversity across states may be due to the dominance of few species in our study (e.g., two species accounted for over $75 \%$ of adults) (Table 1). Simpson's index is heavily weighted toward the most abundant 
species (Magurran 2004). Similarly, other studies observed a lack of difference in Simpson's index for communities with a few dominant species (Mokam et al. 2014, Gogoi et al. 2017).

Trends observed for relative abundance of adult stink bug species and subspecies across states of the North Central Region of the United States (Figs. 2 and 3) were similar to those reported in the literature. For example, E. variolarius is the most common species in northern states (Koch and Pahs 2014, Koch et al. 2017), but relatively uncommon in the south (i.e., below $37^{\circ} \mathrm{N}$ latitude) (McPherson et al. 1993, Smith et al. 2009, Temple et al. 2013). In contrast, C. hilaris is generally more abundant in southern states (Smith et al. 2009, Tindall and Fothergill 2011, Temple et al. 2013). Northern populations of this species appear to result from semi-migratory populations from southern states (Panizzi et al. 2000). Chinavia hilaris prefers soybean and green beans in its southern distribution; however, it feeds on a wider range of hosts in northern areas (Panizzi et al. 2000), which may result in greater dispersal over the landscape and consequently less abundance in any given habitat. Furthermore, $H$. halys, a new invasive species, was more abundant in eastern states (Indiana, Michigan, and Ohio-2016 data not shown), than western states in the region. The higher abundance of $H$. halys in eastern areas can be attributed to its point of introduction in that region and subsequent westward movement (Hoebeke and Carter 2003). Results presented here indicate that $H$. halys has surpassed the relative abundance of several native species in soybean in Michigan and Indiana. We would expect the same to eventually occur over much of the North Central Region of the United States, since it is largely suitable for establishment of H. halys (Zhu et al. 2012, Wallner et al. 2014).

In general, differences in the community of stink bugs across states within the North Central Region of the United States and in comparison to other regions may be driven by differences in geographic distributions and overwintering abilities of the species (McPherson and McPherson 2000), and differences of stink bug species host preference (Tillman et al. 2009, Reay-Jones 2010, Reeves et al. 2010, Herbert and Toews 2011, Venugopal et al. 2014). Because stink bugs colonize other hosts prior to migrating to soybean, the composition of surrounding habitats may influence the species that occupy soybean fields later in the season (Tillman et al. 2009, Reay-Jones 2010, Reeves et al. 2010, Herbert and Toews 2011, Venugopal et al. 2014). 
Differences in landscape composition may also contribute to differences observed across states and regions. The landscape of the North Central Region of the United States is composed predominantly of soybean and corn while the mid-Atlantic and southern regions have more diverse agricultural landscapes (NASS 2017).

Comparison of maximum mean densities of herbivorous stink bugs in our study showed that economic infestations occurred in southern states of the region. In 2016, two fields in Missouri reached the economic threshold for stink bugs for soybean grown for grain (i.e., 10 stink bugs/ 25 sweeps), and nine fields (i.e., five in Missouri, three in Nebraska, and one in Indiana) reached the economic threshold for stink bugs for soybean grown for seed (i.e., 5 stink bugs/ 25 sweeps) (Kogan 1976, Koch et al. 2017). In 2017, no fields reached either of these economic thresholds for stink bugs. Differences in maximum mean abundance of stink bugs observed across states may be attributed to warmer temperatures in southern states. Year to year variability in stink bug abundance, which was also noted by Koch and Pahs (2014) in Minnesota soybean, may be attributed to abiotic factors such as precipitation, winter temperatures and accumulation of degree-days across the season.

The phenology of herbivorous stink bugs observed in soybean fields in the present study (Fig. 5A) may be attributed to landscapelevel movement of stink bugs in search of food resources (McPherson and McPherson 2000, Venugopal et al. 2014). Similar phenological patterns have been observed in other surveys of soybean (Smith et al. 2009, Tillman et al. 2009, Tillman 2011, Temple et al. 2013, Koch and Pahs 2014, Vyavhare et al. 2014, Koch and Rich 2015). Overwintering adults of herbivorous stink bugs emerge in the spring and feed on early-maturing wild and cultivated hosts. As the season progresses, the suitability of early-maturing hosts decreases, and the attractiveness of soybean increases with development of pods and seeds (McPherson and McPherson 2000, Panizzi et al. 2000). The observed first and second peak of herbivorous adult stink bugs (Fig. 5A) are likely resulting from colonizers and adult progeny of those colonizers, respectively.

Populations of predatory stink bugs increased during later soybean growth stages (Fig. 5B). To our knowledge, no studies exist on the phenology of predatory stink bugs in soybean fields. Podisus maculiventris, the most abundant predatory species in our study, is an 
important predator of field crop pests, including larvae of several noctuids (Lepidoptera: Noctuidae) and the Colorado potato beetle (Coleoptera: Chrysomelidae) (Marston et al. 1978, De Clercq 2000). The use of this generalist predator as a biological control of crop pests has been well reviewed (Waddill and Shepard 1975, Marston et al. 1978, De Clercq 2000, Gyawaly and Park 2013). Information presented here on the phenology and maximum mean abundance of $P$. maculiventris across states may improve integration of this predator in integrated pest management programs in the North Central Region of the United States. Specifically, management recommendations should take into consideration the susceptibility of the predatory $P$. maculiventris to insecticides which may be similar to, or greater than, that of herbivorous stink bug species (Tillman and Mullinix 2004).

\section{Conclusions}

Results presented here provide a foundation for the development of integrated pest management programs for stink bugs in soybean in the North Central Region of the United States. Specifically, we provided important basic information on the community composition and phenology of herbivorous and predatory stink bugs that can be used by growers and scientists. More attention should be given to stink bugs in soybean fields in southern areas of the region, where stink bugs more often reached economically damaging infestations. In contrast, areas located in northern areas of the region experienced relatively low levels of risk from stink bugs for soybean production. In general, we demonstrated that the stink bug community of the region is dominated by Euschistus spp. in the northwestern and C. hilaris in the southeastern parts of the region. Furthermore, our study documents that the invasive $H$. halys was among the most abundant species in the eastern part of the region. Therefore, future studies should evaluate the potential impact of management tactics for Euschistus spp., $C$. hilaris and $H$. halys since these are likely the most problematic species in the region.

Acknowledgments - We are grateful to the numerous field and farm staff that maintained fields from which samples were collected; James Menger, Kylie Rich, Pheylan Anderson and Traci Eicholz (University of Minnesota), Lucinda Wallace and Priyanka Mittapelly (The Ohio State University), Nicole Luhr and Terry DeVries 
(University of Nebraska), Patrick Beauzay and Alexander Knudson (North Dakota State University), Taylor Nelson and Larry Bledsoe (Purdue University), Joe Gunn and Tanner Leslie (University of Missouri), and Stephen Losey (Kansas State University) for collecting and processing samples; and Dan Cariveau and Emily SnellRood for reviewing earlier versions of this manuscript. This research was funded by the Hueg-Harrison Fellowship awarded to D.T.P. and the North Central Soybean Research Program.

\section{References}

Acosta, L. G., S. M. Jahnke, L. R. Redaelli, and P. R. S. Pires. 2017. Insect diversity in organic rice fields under two management systems of levees vegetation. Braz. J. Biol. 77: 731-744.

Barcellos, A., L. S. Schmidt, and H. Brailovsky. 2008. Abundance and species richness of Coreoidea (Hemiptera: Heteroptera) from Parque Estadual do Turvo, Southern Brazil. Neotrop. Entomol. 37: 406-412.

Bates, D., M. Mächler, B. Bolker, and S. Walker. 2015. Fitting linear mixed-effects models using Ime4. J. Stat. Softw. 67: 1-48.

Baz, A., B. Cifrián, and D. Martín-Vega. 2014. Patterns of diversity and abundance of carrion insect assemblages in the Natural Park "Hoces del Río Riaza" (central Spain). J. Insect Sci. 14: 162.

Chao, A. 1987. Estimating the population size for capture-recapture data with unequal catchability. Biometrics. 43: 783-791.

Colwell, R. K., and J. A. Coddington. 1994. Estimating terrestrial biodiversity through extrapolation. Philos. Trans. R. Soc. Lond. B. Biol. Sci. 345: 101-118.

Colwell, R. K., A. Chao, N. J. Gotelli, S.-Y. Lin, C. X. Mao, R. L. Chazdon, and J. T. Longino. 2012. Models and estimators linking individual-based and samplebased rarefaction, extrapolation, and comparison of assemblages. J. Plant Ecol. 5: 3-21.

Corrêa-Ferreira, B. S., and J. Azevedo. 2002. Soybean seed damage by different species of stink bugs. Agric. Forest Entomol. 4: 145-150.

De Clercq, P. 2000. Predaceous stink bugs (Pentatomidae: Asopinae), pp. 737-789. In C. W. Schaefer and A. R. Panizzi (eds.), Heteroptera of economic importance. CRC Press, Boca Raton, FL.

DeCoursey, R. M., and C. O. Esselbaugh. 1962. Descriptions of the nymphal stages of some North American Pentatomidae (Hemiptera: Heteroptera).

Depieri, R. A., and A. R. Panizzi. 2011. Duration of feeding and superficial and indepth damage to soybean seed by selected species of stink bugs (Heteroptera: Pentatomidae). Neotrop. Entomol. 40: 197-203.

Evans, E. W. 1985. A key to nymphs of four species of the genus Podisus (Hemiptera: Pentatomidae) of northeastern North America. Proc. Entomol. Soc. Wash. 87: 94-97.

Fehr, W. R., and C. E. Caviness. 1977. Stages of soybean development. Spec. Rep. 80. Cooperative Ext. Serv., lowa State Univ., Ames, IA. 11 pp. 
Gogoi, H., O. Lego, M. Tayeng, and T. Meth. 2017. A Report on insect community and their habitat association in Daying Ering Memorial Wildlife Sanctuary, Arunachal Pradesh. Nat. Acad. Sci. Lett. 40: 257-266.

Gyawaly, S., and Y. L. Park. 2013. Feeding potential and prey acceptance of Podisus maculiventris (Hemiptera: Pentatomidae): implications for biological pest control. J. Plant Biol. Soil Health. 1: 1-5.

Herbert, J. J., and M. D. Toews. 2011. Seasonal abundance and population structure of brown stink bug (Hemiptera: Pentatomidae) in farmscapes containing corn, cotton, peanut, and soybean. Ann. Entomol. Soc. Am. 104: 909-918.

Hoebeke, E. R., and M. E. Carter. 2003. Halyomorpha halys (Stål) (Heteroptera: Pentatomidae): a polyphagous plant pest from Asia newly detected in North America. Proc. Entomol. Soc. Wash. 105: 225-237.

Hopkins, B. W., A. E. Knutson, J. S. Bernal, M. F. Treacy, and C. W. Smith. 2010. Species composition, damage potential, and insecticide susceptibility of stink bugs in cotton in the Lower Gulf Coast Region of Texas. Southwestern Entomol. 35: 19-32.

Hothorn, T., F. Bretz, P. Westfall, and R. M. Heiberger. 2008. multcomp: simultaneous inference in general parametric models. $R$ package version 1.0-0. http://CRAN.R-project.org

Hunt, T., B. Wright, and K. Jarvi. 2011. Stink bug populations developing in soybeans and corn. CropWatch, 4 August 2011. University of Nebraska, Lincoln, NE. http://cropwatch.unl.edu/archive/-/asset publisher/VHeSpfvOAgju/ content/4620945

Hunt, T., B. Wright, and K. Jarvi. 2014. Stink bugs reported in corn and soybeans. CropWatch, 29 July 2014. University of Nebraska, Lincoln, NE. http:// cropwatch.unl.edu/archive/-/asset publisher/VHeSpfvOAgju/content/ stink-bugs-reported-in-nebraska-corn-and-soybeans

Jones, W. A., Jr, and M. J. Sullivan. 1982. Seasonal abundance and relative importance of stink bugs in soybean. South Carolina Agricultural Experiment Station Technical Bulletin. 1087. Clemson University, Clemson, SC.

Kamminga, K. L., D. A. Herbert, Jr, T. P. Kuhar, S. Malone, and A. Koppel. 2009. Efficacy of insecticides against Acrosternum hilare and Euschistus servus (Hemiptera: Pentatomidae) in Virginia and North Carolina. J. Entomol. Sci. 44: 1-10.

Kleijn, D., R. Winfree, I. Bartomeus, L. G. Carvalheiro, M. Henry, R. Isaacs, A. M. Klein, C. Kremen, L. K. M'Gonigle, R. Rader, et al. 2015. Delivery of crop pollination services is an insufficient argument for wild pollinator conservation. Nat. Commun. 6: 7414.

Koch, R. L., and T. Pahs. 2014. Species composition, abundance, and seasonal dynamics of stink bugs (Hemiptera: Pentatomidae) in Minnesota soybean fields. Environ. Entomol. 43: 883-888.

Koch, R. L., and W. A. Rich. 2015. Stink bug (Hemiptera: Heteroptera: Pentatomidae) feeding and phenology on early-maturing soybean in Minnesota. J. Econ. Entomol. 108: 2335-2343. 
Koch, R. L., D. Rider, P. P. Tinerella, and W. A. Rich. 2014. Stink bugs (Hemiptera: Heteroptera: Pentatomidae) of Minnesota: an annotated checklist and new state records. Great Lakes Entomol. 47: 171-185.

Koch, R. L., D. T. Pezzini, A. P. Michel, and T. E. Hunt. 2017. Identification, biology, impacts and management of stink bugs (Hemiptera: Heteroptera: Pentatomidae) of soybean and corn in the midwestern United States. J. Integr. Pest Manag. 8: 1-14.

Koch, R. L., A. Ambourn, and J. Burington. 2018. Detections of Bagrada hilaris (Hemiptera: Pentatomidae) in Minnesota. J. Entomol. Sci. 53: 278-280.

Kogan, M. 1976. Soybean disease and insect pest management, pp. 114-121. In R. M. Goodman (ed.). Expanding the use of soybeans. Proceedings of a Conference for Asia and Oceania. Chiang May, Thailand. INTSOY. Ser. 10.

Leskey, T. C., G. C. Hamilton, A. L. Nielsen, D. F. Polk, C. Rodriguez-Saona, J. C. Bergh, D. A. Herbert, T. P. Kuhar, D. Pfeiffer, G. P. Dively, et al. 2012. Pest status of the brown marmorated stink bug, Halyomorpha halys, in the USA. Outlooks Pest Manage. 23: 218-226.

Magurran, A. E. 2004. Measuring Biological Diversity. Blackwell Publishing, Malden, MA.

Mangiafico, S. 2018. rcompanion: functions to support extension education program evaluation. R package version 2.0.0. https://CRAN.R-project.org/ package $=$ rcompanion

Marston, N. L., G. T. Schmidt, K. D. Biever, and W. A. Dickerson. 1978. Reaction of five species of soybean caterpillars to attack by the predator Podisus maculiventris. Environ. Entomol. 7: 53-56.

McPherson, J. E. 1982. The Pentatomoidea (Hemiptera) of northeastern North America with emphasis on the fauna of Illinois. Southern Illinois University Press, Carbondale, IL.

McPherson, J. E. 2018. Invasive stink bugs and related species (Pentatomoidea): biology, higher systematics, semiochemistry, and management. CRC Press, Boca Raton, FL.

McPherson, J. E., and R. M. McPherson. 2000. Stink bugs of economic importance in America North of Mexico. CRC Press LCC, Boca Raton, FL.

McPherson, R. M., G. K. Douce, and R. D. Hudson. 1993. Annual variation in stink bug (Heteroptera: Pentatomidae) seasonal abundance and species composition in Georgia soybean and its impact on yield and quality. J. Entomol. Sci. 28: 61-72.

McPherson, R. M., L. D. Newsom, and B. F. Farthing. 1979. Evaluation of four stink bugs species from three genera affecting soybean yield and quality in Louisiana. J. Econ. Entomol. 72: 188-194.

Michel, A., R. Bansal, and R. B. Hammond. 2015. Stink bugs on soybean and other field crops. Ohio State University Extension Fact Sheet, ENT- 48. https:// aginsects.osu.edu/sites/aginsects/files/imce/Stink\%20Bugs\%20on\%20 Soybeans\%20and\%200ther\%20Field\%20Crops\%20\%200hioline.pdf 
Mokam, D. G., C. Djiéto-Lordon, and C.-F. B. Bilong. 2014. Patterns of species richness and diversity of insects associated with cucurbit fruits in the southern part of Cameroon. J. Insect Sci. 14: 248.

Nielsen, A. L., and G. C. Hamilton. 2009. Life history of the invasive species Halyomorpha halys (Hemiptera: Pentatomidae) in northeastern United States. Ann. Entom. Soc. Am. 102: 608-616.

Northeastern IPM Center. 2018. Where is BMSB? http://www.stopbmsb.org/ where-is-bmsb/host-plants/

Packauskas, R. 2012. The Pentatomidae, or stink bugs, of Kansas with a key to species (Hemiptera: Heteroptera). Great Lakes Entomol. 4: 210-219.

Paiero, S. M., S. A. Marshall, J. E. McPherson, and M.-S. Ma. 2013. Stink bugs (Pentatomidae) and parent bugs (Acanthosomatidae) of Ontario and adjacent areas: a key to species and a review of the fauna. Can. J. Arthropod Identif. 24: 183.

Palumbo, J. C., and E. T. Natwick. 2010. The Bagrada bug (Hemiptera: Pentatomidae): a new invasive pest of cole crops in Arizona and California. Online. Plant Health Progress. doi:10.1094/PHP- 2010-0621-01-BR

Panizzi, A. R. 2015. Growing problems with stink bugs (Hemiptera: Heteroptera: Pentatomidae): species invasive to the U.S. and potential neotropical invaders. Am. Entomol. 61: 223-233.

Panizzi, A. R., and F. Slansky, Jr. 1985. Review of phytophagous pentatomids (Hemiptera: Pentatomidae) associated with soybean in the Americas. Florida Entomol. 68: 184-214.

Panizzi, A. R., J. E. McPherson, D. G. James, M. Javahery, and R. M. McPherson. 2000. Stink bugs (Pentatomidae), pp. 421-474. In C. W. Schaefer and A. R. Panizzi (eds.), Heteroptera of economic importance. CRC Press, Boca Raton, FL.

Pezzini, D. T., M. Haag, J. Walker, and R. L. Koch. 2018. Pentatomidae (Hemiptera: Heteroptera: Pentatomidae) captured on purple prism traps deployed for detection of emerald ash borer (Agrilus planipennis) (Coleoptera: Buprestidae) in Minnesota. Great Lakes Entomol. 51: 10-17.

R Core Team. 2018. R: a language and environment for statistical computing. R Foundation for Statistical Computing, Vienna, Austria. https://www.Rproject. org/

Reay-Jones, F. P. 2010. Spatial and temporal patterns of stink bugs (Hemiptera: Pentatomidae) in wheat. Environ. Entomol. 39: 944-955.

Reed, D. A., J. C. Palumbo, T. M. Perring, and C. May. 2013. Bagrada hilaris (Burmeister), an invasive stink bug attacking cole crops in the southwestern United States. J. Integr. Pest Manage. 4: C1-C7.

Reeves, R. B., J. K. Greene, F. P. Reay-Jones, M. D. Toews, and P. D. Gerard. 2010. Effects of adjacent habitat on populations of stink bugs (Heteroptera:

Pentatomidae) in cotton as part of a variable agricultural landscape in South Carolina. Environ. Entomol. 39: 1420-1427.

Rider, D. A. 2012. The Heteroptera (Hemiptera) of North Dakota I: pentatomomorpha: pentatomoidea. Great Lakes Entomol. 45: 312-380. 
Simpson, E. H. 1949. Measurement of diversity. Nature. 163: 688.

Sites, R. W., K. Simpson, and D. L. Wood. 2012. The stink bugs (Hemiptera: Heteroptera: Pentatomidae) of Missouri. Great Lakes Entomol. 45: 134-163.

Smith, J. F., R. G. Luttrell, and J. K. Greene. 2009. Seasonal abundance, species composition, and population dynamics of stink bugs in production fields of early and late soybean in South Arkansas. J. Econ. Entomol. 102: 229-236.

Snodgrass, G. L., J. J. Adamczyk, Jr, and J. Gore. 2005. Toxicity of insecticides in a glass-vial bioassay to adult brown, green, and southern green stink bugs (Heteroptera: Pentatomidae). J. Econ. Entomol. 98: 177-181.

Sosa-Gómez, D. R., and F. Moscardi. 1995. Retenção foliar diferencial em soja provocada por percevejos (Heteroptera: Pentatomidae). Anais da Sociedade Entomológica do Brasil. 24: 401-404.

Swanson, D. R. 2012. An updated synopsis of the Pentatomoidea (Heteroptera) of Michigan. Great Lakes Entomol. 45: 263-311.

Temple, J. H., J. A. Davis, S. Micinski, J. T. Hardke, P. Price, and B. R. Leonard. 2013. Species composition and seasonal abundance of stink bugs (Hemiptera: Pentatomidae) in Louisiana soybean. Environ. Entomol. 42: 648-657.

Tillman, P. G. 2011. Influence of corn on stink bugs (Heteroptera: Pentatomidae) in subsequent crops. Environ. Entomol. 40: 1159-1176.

Tillman, P. G., and B. G. Mullinix, Jr. 2004. Comparison of susceptibility of pest Euschistus servus and predator Podisus maculiventris (Heteroptera: Pentatomidae) to selected insecticides. J. Econ. Entomol. 97: 800-806.

Tillman, P. G., T. D. Northfield, R. F. Mizell, and T. C. Riddle. 2009. Spatiotemporal patterns and dispersal of stink bugs (Heteroptera: Pentatomidae) in peanutcotton farmscapes. Environ. Entomol. 38: 1038-1052.

Tindall, K. V., and K. Fothergill. 2011. First records of Piezodorus guildinii in Missouri. Southwest. Entomol. 36: 203-205.

U. S. Department of Agriculture-National Agricultural Statistics Service. 2017. CropScape and Cropland Data Layer. https://nassgeodata.gmu.edu/CropScape/

U. S. Department of Agriculture-National Agricultural Statistics Service. 2018. Agricultural chemical use survey: soybeans. https://www.nass.usda.gov/ Surveys/Guide to NASS_Surveys/Chemical_Use/2017 Cotton_Soybeans Wheat Highlight/ChemUseHighlights Soybeans 2017.pdf

Venugopal, P. D., P. L. Coffey, G. P. Dively, and W. O. Lamp. 2014. Adjacent habitat influence on stink bug (Hemiptera: Pentatomidae) densities and the associated damage at field corn and soybean edges. PLoS One 9: e109917.

Vyavhare, S. S., M. O. Way, and R. F. Medina. 2014. Stink bug species composition and relative abundance of the red-banded stink bug (Hemiptera: Pentatomidae) in soybean in the upper gulf coast Texas. Environ. Entomol. 43: 1621-1627.

Waddill, V., and M. Shepard. 1975. Dispersal of Podisus maculiventris nymphs in soybeans. Environ. Entomol. 4: 233-234.

Wallner, A. M., G. C. Hamilton, A. L. Nielsen, N. Hahn, E. J. Green, and C. R. Rodriguez-Saona. 2014. Landscape factors facilitating the invasive dynamics 
and distribution of the brown marmorated stink bug, Halyomorpha halys (Hemiptera: Pentatomidae), after arrival in the United States. PLoS One 9: e95691.

Wilcox, J. R. 2004. World distribution and trade of soybean, pp. 1-14. In H. R. Boerma and J. E. Specht (eds.), Soybeans: improvement, production, and uses, 3rd ed. ASA-CSSA-SSSA, Madison, WI.

Willrich, M. M., B. R. Leonard, and D. R. Cook. 2003. Laboratory and field evaluations of insecticides toxicity to stink bugs (Heteroptera: Pentatomidae). J. Cotton Sci. 7: 156-163.

Winfree, R., J. W. Fox, N. M. Williams, J. R. Reilly, and D. P. Cariveau. 2015. Abundance of common species, not species richness, drives delivery of a realworld ecosystem service. Ecol. Lett. 18: 626-635.

Zhu, G., W. Bu, Y. Gao, and G. Liu. 2012. Potential geographic distribution of brown marmorated stink bug invasion (Halyomorpha halys). PLoS One 7: e31246. 